Article available at http://www.parasite-journal.org or http://dx.doi.org/10.1051/parasite/1998054331

\title{
MYXOSPOREANS AND COCCIDIANS PARASITIC ON ENGRAULID FISHES FROM THE COASTS OF ARGENTINA AND URUgUaY
}

\author{
TIMI J.T.*** \& SARDELLA N.H.*
}

\section{Summary :}

Two new species of the genus Sphaeromyxa (Myxosporea) from the gall bladder and one new species of the genus Eimeria Coccidial parasitizing the testes, are reported from engraulid fishes from the Argentinian shelf lincluding the ArgentineanUruguayan Common Fishing Zonel: Sphaeromyxa bonaerensis $n$. sp., found in Engraulis anchoita Hubbs \& Marini, 1935 largentine anchovy) (prevalence $0.2 \%$ ) and in Anchoa marini Hildebrand, 1943 (anchovy) (prevalence $24.2 \%$ ) caught in the Bonaerense region of the Argentinian Sea; Sphaeromyxa argentinensis $n$. sp. found in $E$. anchoita from all the sampled localities between $34^{\circ} \mathrm{S}$ and $46^{\circ} \mathrm{S}$ (prevalence $26.8 \%$ ) and from A. marini at Mar del Plata coastal zone (prevalence $1.01 \%$. Eimeria patagonensis $\mathrm{n}$. sp. was found in $E$. anchoita living in the Patagonian region of the Argentine Sea (prevalence $0.45 \%$ ). Details of some ultrastructural features of $S$. argentinensis are provided.

KEY WORDS : Sphaeromyxa, Eimeria, Engraulis anchoita, Anchoa marini, parasites, Argentina, Uruguay.
Résumé : MYXOSPORIDIES ET COCCIDIENS PARASITES DES POISSONS DE. la famille Engraulidae provenant des Côtes d'Argentine eT D'URuguar

Deux nouvelles espèces du genre Sphaeromyxa (Myxosporea) parasites de la vésicule biliaire et une nouvelle espèce appartenant au genre Eimeria (Coccidia) parasite des testicules, sont signalées chez des poissons de la famille Engraulidae, provenant des côtes d'Argentine (comprenant la Zone de Pêche Commune Argentine-Uruguay). Sphaeromyxa bonaerensis n.sp. a été trouvée chez Engraulis anchoita Hubbs \& Marini, 1935 lanchois d'Argentine), (prévalence: 0,2\%) et chez Anchoa marini Hildebrand, 1943 (anchois) (prévalence : 24,2\%) récoltés sur les côtes de la province de Buenos Aires. Sphaeromyxa argentinensis ก.sp. a été recoltée chez $\mathrm{E}$. anchoita provenant des prélèvements obtenus entre $34^{\circ} \mathrm{S}$ et $46^{\circ} \mathrm{S}$ (prévalence : $26,8 \%$ ), et chez $\mathrm{A}$. marini capiuré dans les eaux côtières de Mar del Plata (prévalence: 1,01\%). Eimeria pałagoniensis a été trouvée chez $\mathrm{E}$. anchoita provenant des eaux de la région Patagonique d'Argentine (prévalence: 0,45\%). Les nouvelles especes sont décrites el figurées. Quelques caractéristiques ultrastructurales de S. argentinensis sont indiquées.

MOTS CLES : Sphaeromyxa, Eimeria, Engraulis anchoita, Anchoa marini, parasites, Argentine, Uruguay

in the area is the coccidian parasitic fauna, represented at present by Goussia clupearum (as Eimeria clupearum) (Evdokimova, 1973), Eimeria jadvigae (Grabda, 1983) and Goussia sp. (MacKenzie \& Longshaw, 1995).

In the course of a parasitological survey of the anchovies Engraulis anchoita Hubbs \& Marini, 1935 (argentine anchovy) and Anchoa marini Hildebrand, 1943 (anchovy) caught in the Argentinean Shelf, representatives of two new species of the genus Sphaeromyxa Thelohan, 1895 and one new species of the genus Eimeria Schneider, 1875 were found; these parasites are described in the present paper.

\section{MATERIALS AND METHODS}

\footnotetext{
- Laboratorio de Parasitología, Departamento de Biología, Facultad de Ciencias Exactas y Naturales, Universidad Nacional de Mar del Plata, Funes 3350, (7600) Mar del Plata, Argentina.

** Consejo Nacional de Investigaciones Científicas y Técnicas (CONICET).

Correspondence: J.T. Timi

Tel: 54-023-752426 - Fax: 54-023-753150 - e-mail: jtimi@mdp.edu.ar
}

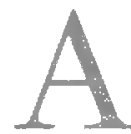

total of 1,891 specimens of Engraulis anchoita Hubbs \& Marini, 1935 and 99 specimens of Anchoa marini Hildebrand, 1943, were examined. 
The samples of $E$. anchoita were collected during the research cruises of R.V. Cap. Oca Balda and R.V. Dr. E. Holmberg (Instituto Nacional de Investigación y Desarrollo Pesquero (INIDEP)) OB 11/93 (October, 1993), OB 13/93 (November-December, 1993), H 04/94 (May, 1994), O13 08/94 (October, 1994), H 07/95 (September, 1995) and OB3 14/95 (October, 1995), which covered the South West Atlantic shelf from $34^{\circ} \mathrm{S}$ to $46^{\circ} \mathrm{S}$. The samples of $A$. marini were obtained in May, 1996 and June, 1998, from commercial catches at Mar del Plata Port ( $\left.38^{\circ} 08^{\prime} \mathrm{S}-57^{\circ} 32^{\prime} \mathrm{W}\right)$.

Fish were fixed in buffered $10 \%$ formalin and transported to the laboratory, where they were dissected out and examined under a stereoscopic microscope.

Prevalence (percentage of parasitized fish) and intensity (number of parasites per host, calculated only for myxosporidian plasmodia) of infections were calculated according to Margolis et al. (1982) terminology.

The myxosporidians were studied in wet smears of the gall bladders. Air dried smears were refixed in methyl alcohol and stained with Giemsa's stain to highlight details of spore morphology. In a subsample of 30 specimens of $E$. anchoita and 20 specimens of $A$. marini the gall bladders were dissected out and the vegetative forms were removed with the aid of dissection needles. The vegetative forms and spores were measured.

For transmission electron microscopy (TEM) and scanning electron microscopy (SEM) a sample of fresh plasmodia was recovered from 30 fresh specimens of E. anchoita obtained from commercial catches at Mar del Plata Port (October, 1995). These anchovies were not inclucled in the quantitative clata. Plasmodia were fixed for $24 \mathrm{~h}$ at $4{ }^{\circ} \mathrm{C}$ with $3 \%$ glutaraldehyde in $0.1 \mathrm{M}$ cacodylate buffer at $\mathrm{pH} 7.4$ and post-fixed for $1 \mathrm{~h}$ at $4^{\circ} \mathrm{C}$ with $1 \%$ osmium tetroxide in $0.1 \mathrm{M}$ cacodylate buffer at $\mathrm{pH} 7.4$. After fixation the material was dehydrated in progressive ethanol series and then for TEM observations the plasmodia were embeclded in Spur at $70^{\circ} \mathrm{C}$, ultrathin sections were stained with lead citrate and uranyl acetate and observed in a Jeol T100 CX II TEM. For SEM observations, the specimens were subjected to $\mathrm{CO} 2$ critical point drying, coated with goldpalladium and scanned in a Jeol T100 SEM.

Descriptions of myxosporidians were made following Lom \& Arthur (1989).

The coccidians were checked by squash method in only those testes showing transparent subepithelial spots under stereoscopic microscope and studied in wet smears.

Drawings were made with the aid of a camera lucida. Collection number quoted refers to specimens deposited at the La Plata Natural Sciences Museum (LPNSM), Lá Plata, Argentina.

\section{RESULTS}

SPHAEROMYXA BONAERENSIS N. SP. (Figs. 1, 4)

Type host: Anchoa marini Hildebrand, 1943. Other host: Engraulis anchoita Hubbs \& Marini, 1935. Type material: Giemsa stained spores, LPNSM Collection number: 002/1; one fixed plasmodium, LPNSM Collection number: 002/2.

Location in hosts: gall bladder.

Locality: Mar del Plata Port $\left(38^{\circ} 08^{\prime} \mathrm{S}-57^{\circ} 32^{\prime} \mathrm{W}\right)$; $37^{\circ} 22^{\prime} \mathrm{S}-56^{\circ} 21^{\prime} \mathrm{W} ; 37^{\circ} 30^{\prime} \mathrm{S}-56^{\circ} 50^{\prime} \mathrm{W} ; 39^{\circ} 13^{\prime} \mathrm{S}-$ $60^{\circ} 20^{\prime} \mathrm{W} ; 38^{\circ} 51^{\prime} \mathrm{S}-58^{\circ} 43^{\prime} \mathrm{W}$.

Date: October, 1993; October, 1994; September, 1995.

Prevalence of infection: in $A$. marini 24 out of 99 (24.2\%), in E. anchoita four out of 1,891 (0.2\%).

Intensity (number of plasmodia per host): one.

Etymology: the specific name refers to the geographic zone where the species was found.

\section{DESCRIPTION}

Spores: the spores are fusiform, slightly arcuate in valvular view; straight in sutural view and with truncated ends. The shell valves are longitudinally striated. The sutural ridge is oblique. The two oval and equal polar capsules are situated on each end of the spore. The polar filament makes five longitudinal folds in the capsule. The capsular nuclei are sometimes visible beneath the polar capsules. The space between the polar capsules is filled with a finely granular sporoplasm. Two sporoplasm nuclei are often visible.

Measurements in micrometers, based on 20 spores from A. marini (Type host); mean is followed by the range in parentheses: spore length: 17.33 (16.50-18.75); spore width: $4.45(3.75-4.80)$; spore thickness: 4.16
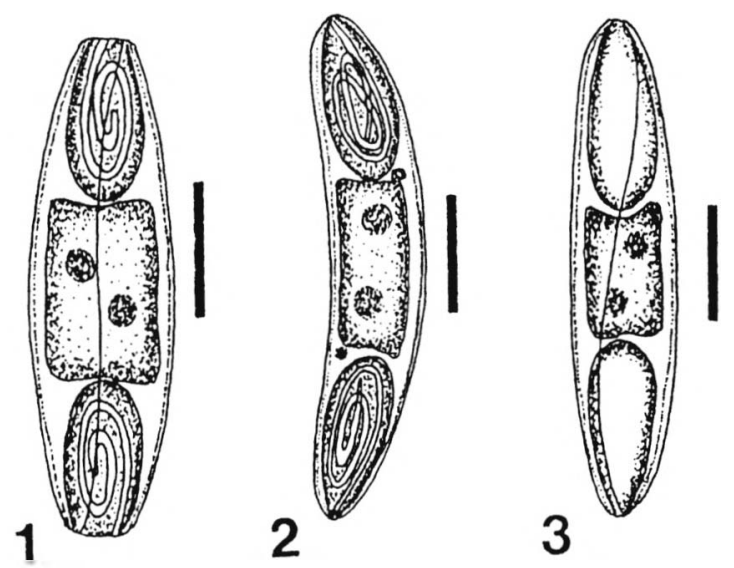

Figs. 1-3. - Fig. 1. Sphaerumyxa. bonaerensis n. sp., spore, sutural view. Fig. 2. Sphaeromyxa argentinensis n. sp., spore, valvular view. Fig. 3. S. argentinensis n. sp., spore. sutural view. Bars: $5 \mu$. 
(3,45-4,50); polar capsule length: 4.08 (3.00-4.50); polar capsule width: 2.81 (1.95-3.30). Measurements of 10 spores from $E$. anchoita were coincident with those from the Type host.

Vegetative form: the plasmodium is found floating freely in the gall bladder fluid, coiled upon itself. Attempts to unfold the plasmodia were unsuccessful because they were obtained from fixed hosts. Maximum diameter, based upon two folded plasmodia: $1.10 \mathrm{~mm}$ and $1.53 \mathrm{~mm}$ respectively.

\section{REMARKS}

Laird (1953) divided the genus Sphaeromyxa into two groups, the balbianii group with straight or slightly curved fusiform or ovoid spores, having ovoid polar capsules and the incurvata group with arcuate spores, having pyriform polar capsules. The species described above belongs to the balbianii group.

In the Argentine Sea, so far only one species of Sphaeromyxa has been recorded: S. schulmani Kovaleva \& Gaevskaya, 1982 parasitizing Salilota australis. This species also belongs to the balbianii group; it can be distinguished from the new species by having smaller spores $(18.6-20.0 \mu \times 4.0-5.98 \mu)$, larger polar capsules (4.65-5.98 $\mu \times 2.66-3.32 \mu$ ), smooth spore valves and one sporoplasm nucleus (Kovaleva \& Gaevskaya, 1982)

Love \& Moser (1983) cited the presence of $S$. reinhardti Jameson, 1929 in another engraulid species, Engraulis mordax from the Pacific coast of United States. This species belongs to the balbianii group, but its spores, according with the description of Jameson (1929) are larger than those of the new species $(21.25-23.30 \mu \times$ 3.75-5.00 $\mu$ ).

The new species resembles $S$. balbianii Thélohan, 1892, a parasite of several fish species from the Mediterranean Sea, the Adriatic Seal, the Atlantic coasts of Europe, Canada and the United States and West Africa (Senegal) (Laird, 1953; Khan et al., 1986; Lubat et al., 1989; Kpatcha et al., 1996; Gracia et al., 1997). S. balbianii differs from the new species by having wider spores $(5.00-9.50 \mu)$ and larger polar capsules (6.0-7.0 $\mu$ $\times$ 3.0-4.7 4) (Laird, 1953; Khan et al., 1986; Lubat et al., 1989). Nevertheless, Kpatcha et al. (1996) reported a smaller length in the spores of $S$. balbianii from Senegal than those from European and North American waters $(13.5-14.6 \mu)$; these measurements are even smaller than those of the species described in the present paper.

The other members of the balbianii group are readily distinguished from the new species by having spores of different size (Noble, 1939, 1941; Laird, 1953; Schulman, 1966).

On the basis of the differences listed above, a new species, Sphaeromyxa bonaerensis, is proposed.
The values of prevalence in both host species suggest that $A$. marini is the main host for this myxosporean in the studied area. This assumption is supported by the presence of $S$. bonaerensis $n$. sp. only in specimens of $E$. anchoita proceeding from the area where both host species overlap their distributions (Northern zone) (Fuster de Plaza \& 13oschi, 1961).

SPHAEROMYXA ARGENTINENSIS N. SP. (Figs. 2-3, 5-13) Type host: Engratlis anchoita Hubbs \& Marini, 1935. Other host: Anchoa marini Hildebrand. 1943.

Type material: Giemsa stained spores, LPNSM Collection number: 003/1; two fixed plasmodia. LPNSM Collection number: $003 / 2$.

Location in hosts: gall bladder.

Locality: all sampled localities in the Argentine sea. Date: October-December, 1993; May, October, 1944; September-October, 1995.

Prevalence of infection: in E. anchoita 506 out of $1,891(26.8 \%)$, in A. marini one out of $99(1.01 \%)$. Intensity (number of plasmodia per host) : one-four. Etymology: the specific name is derived from the presence of this species along the coast of Argentina.

\section{DESCRIPTION}

Spores (Figs, 2-3, 5-11): the spores are elongate and fusiform, arcuate in valvular view, sometimes
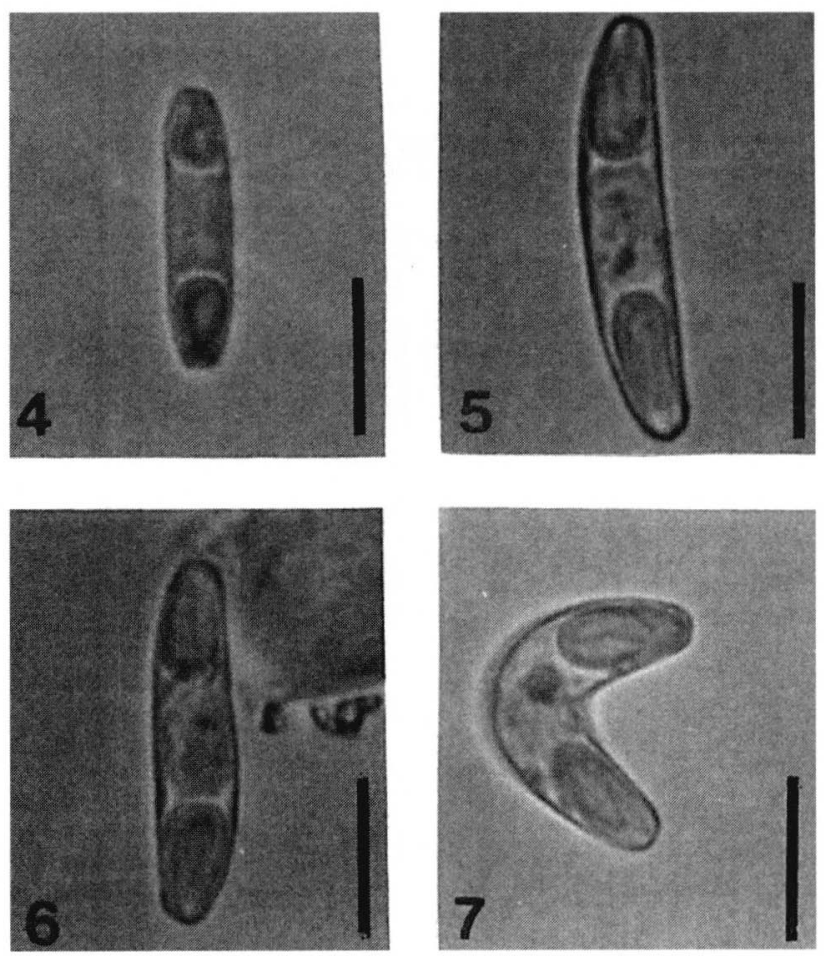

Figs. 4-7. - Fig. 4. Spbaeromyxa bonaerensis n. sp., spore, valvular vicw. Fig. 5. Spbaeromyza argentinensis n. sp., spore, valvular view Fig. 6. S. angentinensis n. sp., "S"-shaped spore. Fig. 7. S. argentinensis n. sp., "U"-shaped spore, 13ars: $10 \mu$. 

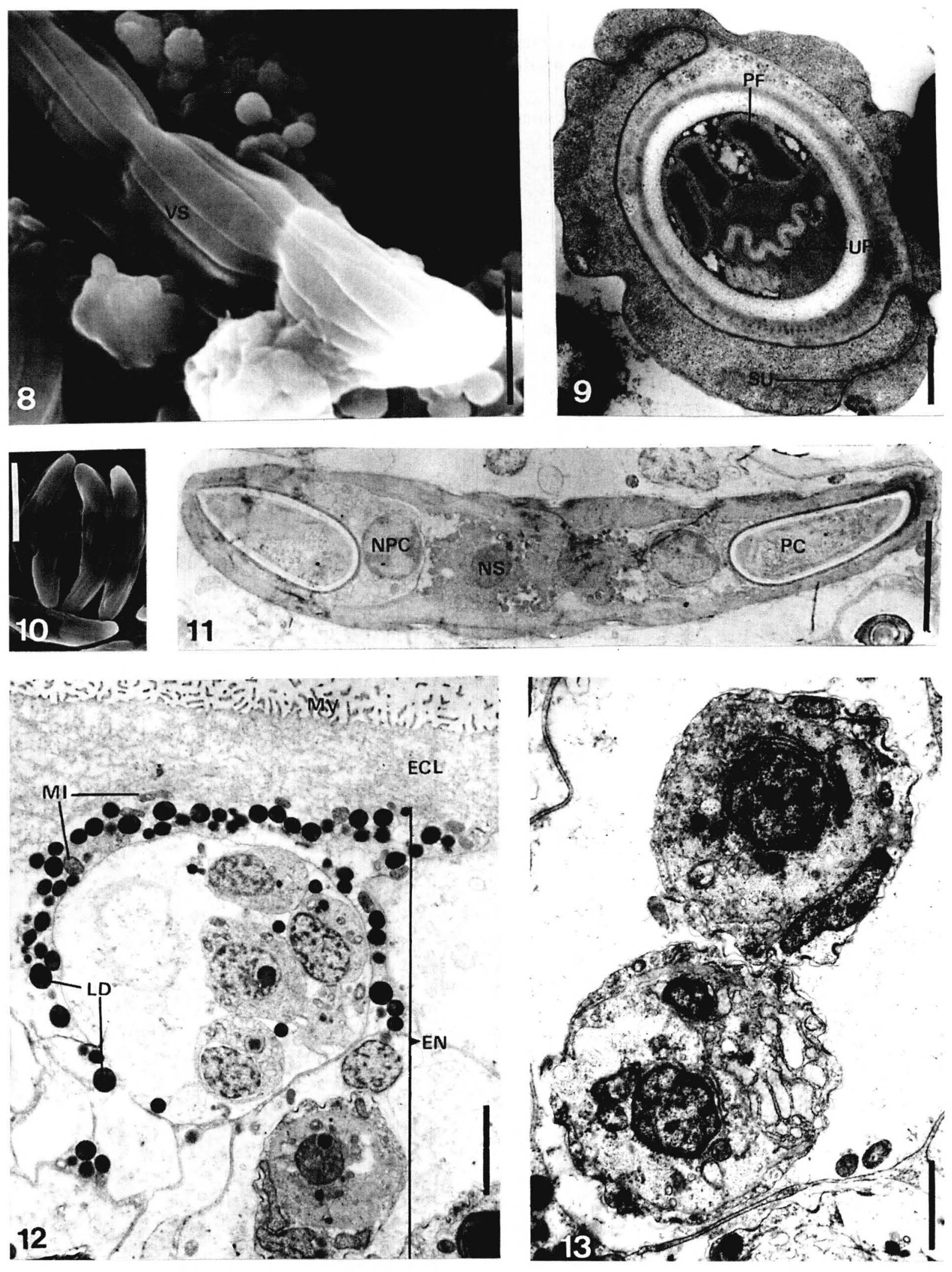

Figs, 8-13. - Spores and plasmodium of Spbaeromyxa argentinensis n. sp. Fig. 8. SEM image of spore, vS: valvular striations (har: $10 \mu \mathrm{m}$ ). Fig. 9. TEM image of cross section of developing spore, SU: suture, UPF: undulate section of polar filament, PF: polar filament (bar: $0.5 \mu m$ ). Fig. 10. SEM image of spores. Fig. 11. TEM image of longitudinal section of developing spore, PC: polar capsule, SP: sporoplasm, NPC: nucleus of polar capsule, NS: nucleus of sporoplasm (bar: $10 \mu \mathrm{m}$ ). Fig. 12. TEM image of cross section of plasmodium, MV: microvillosities, ECL: ectoplasmic layer, EN: endoplasm, MI: mitochondria, LI): lipid droplets (bar: $4 \mu \mathrm{m}$ ). Fig. 13. TEM image of disporeous pansporoblast (bar: $2 \mu \mathrm{m}$ ). 
"S"-shaped and exceptionally "U"-shaped; straight in sutural view and with bluntly rounded ends. SEM examination of spores evidenced longitudinally striated shell valves and "S"-shaped sutural ridge. The two equal pyriform polar capsules are situated on each end of the spore. TEM examination of spores showed the polar capsules opening sub-apically and the polar filament making five longitudinal folds in the capsule: the polar filament has an undulate proximal part in cross section and a compressed distal end. The capsular nuclei are sometimes visible beneath the polar capsules. The space between the polar capsules is filled with a finely granular sporoplasm. Two sporoplasm nuclei are often visible.

Measurements in micrometers, based on 20 spores from $E$. anchoita (Type host); mean is followed by the range in parentheses: spore length: $24.90(23.25-27.50)$; spore width: 4.78 (4.50-5.25); spore thickness: 4.95 (4.50-5.25); polar capsule length: 7.25 (6.00-9.00); polar capsule width: $3.32(2.55-4.50)$. Measurements of ten spores from $E$. anchoita were coincident with those from the Type host.

Vegetative form and sporogenic stages: the plasmodium is found floating freely in the gall bladder fluid, coiled upon itself. Unfolded plasmodium is discoidal to oval, measuring in fresh condition 1.9 to 4.4 by 2.0 to $4.7 \mathrm{~mm}$, some of them exceeding the gall bladder itself in length and breadth.

TEM examination of plasmodium (Figs. 12-13) showed network of microvillosities covering its external surface. In cross section, an ectoplasmic layer covering a vacuolated endoplasm is observed. As the ectoplasm passes into the endoplasm, there is a concentration of mitochondria and lipid droplets. The endoplasm has a vacuolated appearance, with vegetative nuclei, generative cells, developing sporoblasts and ripe spores floating among the vacuoles. The pansporoblasts are all disporous.

\section{REMARKS}

The species described above is a member of the incurvata group (Laird, 1953); there are five species of Sphaeromyxa belonging to this group. which show resemblance in the spore size with the new species: S. sabrazesi Laveran \& Mesnil, 1900, from the Mediterranean Sea and the Atlantic coasts of Europe (Laird, 1953. Lubat et al, 1989); S. hellandi Auerbach, 1909, from the Atlantic coasts of Norway and Barents Sea (Laird, 1953; Schulman, 1966); S. maiyai Morrison \& Pratt, 1973 from the Oregon coasts (United States of America) (Morrison \& Pratt, 1973); S. dighae Sarkar \& Majumder, 1983 from the Bay of Bengala (India) (Sarkar \& Majumder, 1983) and S. hareni Sarkar, 1984, from India (Sarkar, 1984).

However, according to Laird (1953), S. sabrazesi has slender spores (3.0-4.30 $\mu)$, longer polar capsules (8.0-
$10.0 \mu)$ and truncated ends, although Lubat et al. (1989) reponted larger sized spores (28-30 $\mu$ ) and polar capsules $(10.5 \mu)$ in some specimens from the coasts of Montenegro (Adriatic Sea). $S$. hellandi differs from the new species in having widder spores $(5.4 \mu)$, larger polar capsules (10-10.8 $\mu$ ) and truncate ends (Laird. 1953), although Schulman (1966) cited smaller spores $(20.5-23 \mu)$ for this species. S. maiyai shows widder spores $(5.6 \mu)$ and longer polar capsules $(9.3 \mu)$ (Morrison \& Pratt, 1973). S. dighae has slender spores (3.33) and ellipsoidal polar capsules $(2.32 \mu$ ) (Sarkar \& Majumder, 1983). Finally S. hareni shows smooth and thicker spores (5.60-8.87 $\mu$ ) and oval to ellipsoidal longer polar capsules (8.87-10.27 $\mu$ ) (Sarkar, 1984). Other described species, members to the incuruata group, differs from the new species in the dimentions of the spores and/or polar capsules (Laird, 1953; Sarkar, 1984; Schulman, 1966; Su \& White, 1994).

The ultrastructural features of the plasmodia and the developmental stages of the spores agree with the findings of Lom (1969), exhibiting structural patterns apparently common to all species of Sphaeromyxa. On the basis of the differences listed above, a new species Sphaeromyxa argentinensis $\mathrm{n}$. sp. is proposed. The values of prevalence in both host species suggest that $E$. anchoita is the main host for $S$. argentinensis n. sp. in the stuclied area.

\section{EIMERIA PATAGONENSIS N. SP. (Figs. 14-21)}

Type host: Engraulis anchoita Hubbs \& Marini, 1935. Type material: one parasitized testes preserved in formalin 4\%, LPNSM Collection number: 004 .

Location in host: testes.

Date: October, 1995.

Number of males parasitized: four of 892.

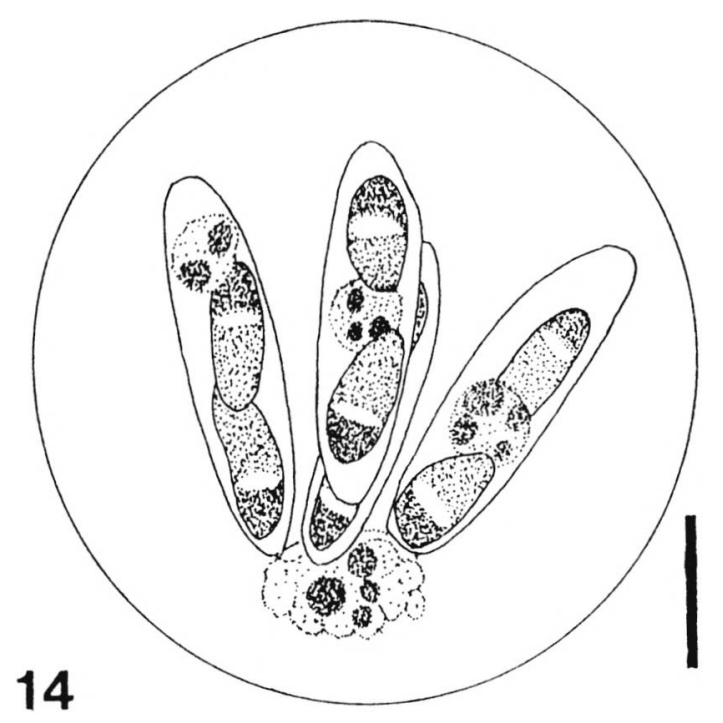

Fig. 14. - Eimeria patagonensis n. sp, mature oocyst (bar: $10 \mu \mathrm{m}$ ). 

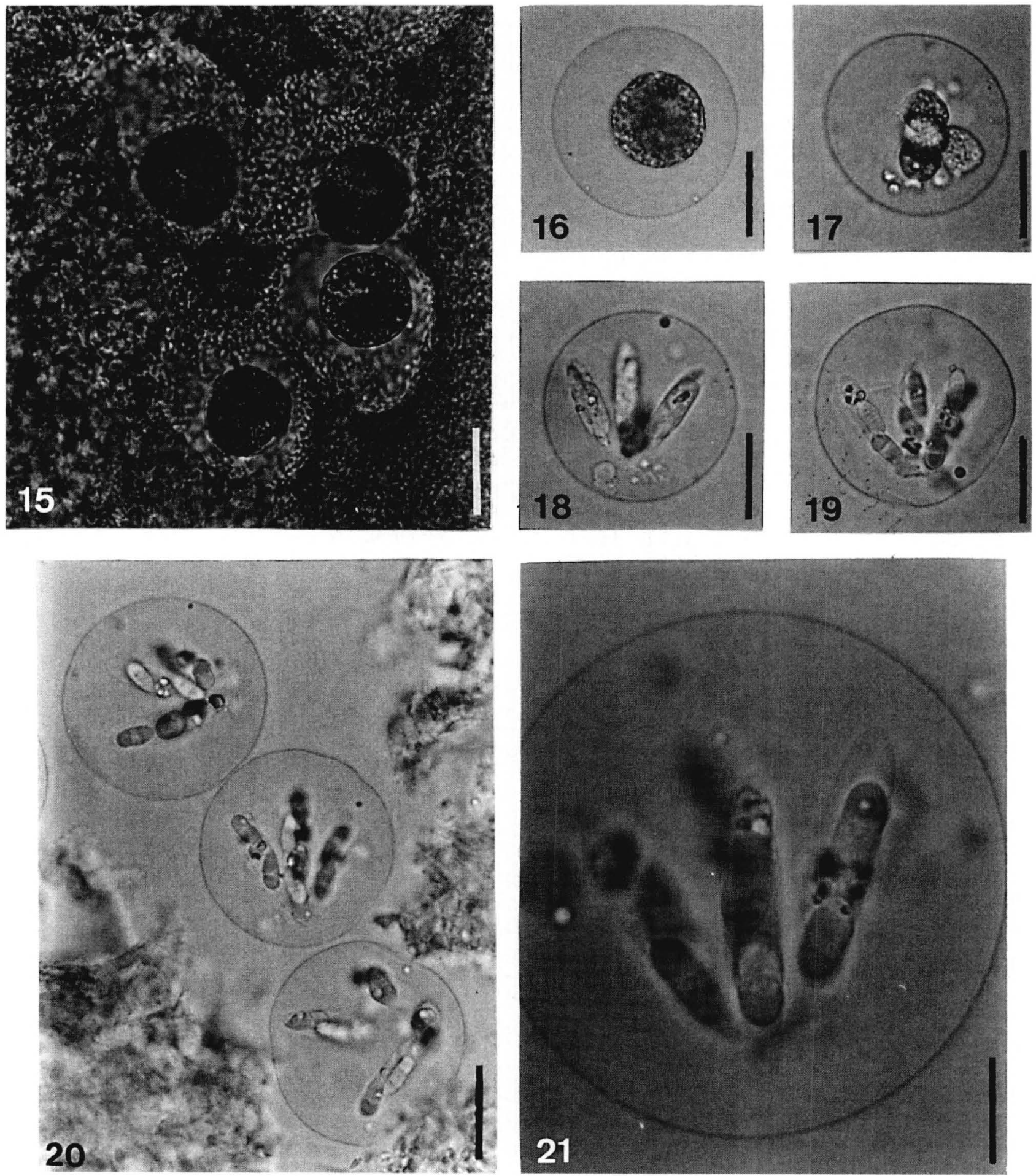

Figs. 15-21. - Eimeria patagonensis n. sp. Fig. 15. young oocyst in testes (tissue impression) (bar: 25 um). Fig. 16. young oocyst (bar: $25 \mu \mathrm{m}$ ). Fig. 17. oocysts containing sporoblasts (bar: $25 \mu \mathrm{m}$ ). Fig. 18. oocysts containing developing sporocysts (bar: $25 \mu \mathrm{m}$ ). Figs. 19-20. mature oncysts (bar: $25 \mu \mathrm{m}$ ). Fig. 21. detail of mature oocyst (bar: $10 \mu \mathrm{m}$ ). 
Prevalence of infection: including all the samples: four out of 892 males $(0.45 \%)$; in the parasitized sample $\left(42^{\circ} 45^{\prime} \mathrm{S}-60^{\circ} 40^{\prime} \mathrm{W}\right)$ : four out $26(15.4 \%)$.

Etymology: the specific name refers to the geographic zone where the species was found.

\section{DESCRIPTION}

Undivided oocysts (Figs. 15-16), oocysts containing sporoblasts (Fig. 17) and oocysts containing developing sporocysts (Fig. 18) were observed. Mature oocysts (Figs. 14, 19-21) thin-walled and sphaerical and with no micropyle or polar granule. Oocyst residuum composed by three or four coarse refringent granules, immersed in a thin mass. Sporocyst elongated and fusiform, does not fill the entire oocyst, forming a triradiate star or a pyramid, confluent extremes in contact with the oocyst residuum. Stieda body absent. Sporozoites ovoid, not in contact with the sporocyst wall, laying head to tail with the sporocyst residuum at one end, or situated one after other with the sporocyst residuum in the center. Sporocyst residuum in form of two to four coarse refractile granules embedded in a sphaerical transparent mass. Measurements in micrometers, based on 20 mature oocysts from only one fish; mean is followed by the range in parentheses: oocyst diameter: 43.3 (43.0-44.1); oocyst residuum: 12.7 (11.9-13.0) × 15.5 (15.1-16.5); sporocyst length: 31.9 (30.9-33.0); sporocyst width: 8.0 (7.2-8.2); sporozoite length: 10.3 (8.2-12.4); sporozoite width: 5.3 (4.1-6.2); sporozoite residuum diameter: 5.1 (4.1-6.2).

In undivided and immature oocysts from other host specimens, the measurements based on 20 specimens were: oocyst diameter: 57.1 (43.3-59.8); immature sporocyst length: 28.2 (25.8-30.9); immature sporocyst width: $7.5(6.5-8.2)$.

\section{REMARKS}

Records of eimeriid species parasitizing the testes of fish form Argentina are inexistent. In the North Hemisphere, species belonging to the genus Eimeria have been reported from the testes of clupeiform fishes: Eimeria sardinae (Thélohan, 1895) from the Atlantic Ocean (Dyková \& Lom, 1983; Lom \& Dyková, 1992; Diouf \& Toguebaye, 1994) and the Adriatic Sea (Daoudi et al., 1989); E. nishin Fujita, 1934 from the Pacific Ocean (Arthur \& Arai, 1980); E. brevoortiana Hardcastle, 1944 from the Atlantic (Hardcastle, 1944; Lom \& Dyková, 1992; Upton et al., 1984) and E. ethmalosae Diouf \& Toguebaye, 1994 from the Senegal coasts (Diouf \& Toguebaye, 1994).

The new species can be distinguished from all the species listed above by having a big oocyst residuum and by the arrangement of the sporocysts in the oocyst (triradiate star or pyramid).
The dimentions of the new species overlap the measurements range of $E$. sardinae given by Lom \& Dyková (1992) (oocyst diameter: $40-60 \mu$, sporocysts: $25-35 \times 7-8 \mu$ ), but this species has vermiform sporozoites and a small oocyst residuum. Daoudi et al. (1989) reported smaller sized oocysts $(31-40 \mu)$ in specimens from $S$. aurita from the Adriatic Sea, although the sporocysts have similar dimensions (24-32 $\times 7-9 \mu$ ) than those of the new species.

Diouf \& Toguebaye (1994) found a great variability in the size of the oocysts of E. sardinae from Sardinella aurita and $S$. maderensis in Senegal coasts and reported the presence of Stieda body in giant-sized oocysts from S. aurita. Nevertheless, E. sardinae does not have Stieda body (Morrison \& Hawkins, 1984); this feature, as well as the great variability of measurements found by Diouf \& Toguebaye (1994), could indicate that there are more than one species parasitizing both hosts.

No differences between E. nishin and E. sardinae were found by Arthur \& Arai (1980), who suggested that they might be considered as a synonymy.

The oocysts of E. ethmalosae are variable in size (27$53 \mu$ ) (Diouf \& Toguebaye, 1994), but this coccidian differs from the species described above by having ellipsoidal sporocysts, Stieda body and vermiform sporozoites.

Eimeria brevoortiana has smaller oocysts and sporocysts $(17.5-30 \mu$ and $16.4 \times 6.3 \mu$, respectively), and the sporozoites are cigar-shaped (Hardcastle, 1944; Upton et al., 1984).

Based upon these differences and taking into account the host species and the geographic procedence of this coccidian, a new species, Eimeria patagonensis, is proposed.

The observed differences in size between mature and immature oocysts from different hosts could be due to the developmental stage and/or to a great intraspecific variability also observed in other species of Eimeria from the testes of fishes, such as E. sardinae and $E$. ethmalosae (Diouf \& Toguebaye, 1994).

\section{ACKNOWLEDGEMENTS}

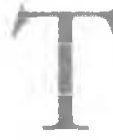
he authors wish to thank Lic. Marcelo Pájaro, Dr. Jorge Hansen and Dr. Ricardo Perrota (Instituto Nacional de Investigación y Desarrollo Pesquero) for providing and conditioning the anchovy samples, to Lic. Mariela Radonic and Ms. Silvana Campodónico for providing the sample of Anchoa marini, to Lic. Monica Oppedissano by processing the samples for scanning and transmission electron microscopy, to Dr. Ken MacKenzie (University of Aberdeen, Scotland, UK) for his help with a part of the bibliography and 
specially to Dr. Iva Dyková (Institute of Parasitology, Academy of Sciences of the Czech Republic) for her critical revision of the manuscript. This work was partially carried out with the financial support of University of Mar del Plata Grant E/117/97.

\section{REFERENCES}

Arthur J.R. \& ARAI H.P. Studies on the parasites of Pacific herring (Clupea barengus pallasi Valenciennes): a preliminary evaluation of parasites as indicators of geographical origin for spawning herring. Canadian Journal of Zoology, $1980,58,521-527$

Daoudi F., Radujkovic B.M., Marques A. \& BoulX G. Parasites des poissons marins du Montenegro: Coccidies. Acta Adriatica, 1989, 30, 13-30.

Diouf J.N. \& Togueliaye B.S. Study of some marine fish Coccidia of the genus Eimeria Schneider, 1815 (Apicomplexa, Coccidia) from Senegal coasts. Acta Protozoologica, 1994, $33,239-250$.

Dykovì I. \& Lom. J. Fish Coccidia: an annotated list of described species. Folia Parasitologica, 1983, 30, 193-208.

Evdokimova E.B. Parasitofauna of commercial teleost fishes at the Patagonian Shelf. Zoologichevskii Institute Akadenija NAUK, CCCP, Kaliningrad, Thesis, 1973, 18 p. (in Russian).

Fuster de Plaza M.L. \& Boschi E.E. Nuevos datos sobre la biología de la especie Anchoa marini de Mar del Plata. Actas y Trabajos del Primer Congreso Sudamericano de Zoología, 1961, 4, 55-68.

Gafvikaya A.V., Kovaleva A. \& Roljuk G.N. Parasitofauna of the fishes of the Falkland-Patagonian Region. In. Hargis W.J. Jr. (Ed.), Parasitology and pathology of marine organisms of the World Ocean. NOAA Technical Report NMFS $25,1985,25-28$.

Gralisa E. Eimeria jadvigae n. sp. (Apicomplexa: Eucoccidia), a parasite of swimming bladder of Coryphaenoides bolotracbys (Günter, 1887) off the Falklands. Acta Ichtbyologica et Piscatoria, 1983, 13, 131-140.

Gracia M.P., Malllo P.A., Amigó, J.M. \& Salvadó H. Ultrastructural study of Spbaeromyxa balbianii, Thélohan 1892 (Myxozoa, Myxosporea: Bivalvulida), a parasite of Cepola macrophtalma, Linnaeus 1758. Acta Protozoologica, 1997, 36, 171-179.

Hariscastle A.B. Eimeria brevoontiana, a new sporozoan parasite from menhaden (Brevoortia tyrannus), with observations on its life history. Journal of Parasitology, 1944, $30,60-68$.

JAMESON A.P. Myxosporidia from California fishes. Journal of Parasitology, 1929, 16, 59-68.

Kal.avati C., Longshaw M. \& MacKenzie K. Two species of protozoan parasites (Myxosporea: Bivalvulida), one new, from Merluccius australis and M. bubbsi (Pisces: Teleostei) in the South West Atlantic and South East Pacific. Journal of Natural History, 1995, 29, 865-870.

Kalavati C., Longshaw M. \& MacKenzie K. Two species of myxozoan parasites (Myxosporea: Bivalvulida), including a new genus, from Patagonotothen sima (Richardson, 1845) (Pisces: Teleostei) in The South West Atlantic. Systematic Parasitology, 1996, 34, 67-70.

Khan R.A., Bowering W.R., Blzgeois C., Lear H. \& Pippy J.H. Myxosporean parasites of marine fish from the continental shelf off Newfoundland and Labrador. Canadian Joumal of Zoology, 1986, 64, 2218-2226.

Kovaleva A.A. \& Gafvskaya A.V. New data on Myxosporidia from the South-Western Atlantic fishes. Parazitologiya, 1982, 16, 353-359.

Kpatcha T.K., Diebakate C. \& Togueibaye B.S. Myxosporidies (Myxozoa, Myxosporea) des genres Sphaeromyxa Thélohan, 1892, Myxidium Bütschli, 1882, Zscbokkella Auerbach, 1910, Bipteria Kovaljova, Zubtchenko \& Krasin, 1983 et Leptotheca Thélohan, 1895 parasites des poissons des côtes sénégalaises (Afrique de l'Ouest). Journal of African Zoology, 1996, 110, 309-317.

LAIR1) M. The Protozoa of New Zealand intertidal zone fishes. Transactions of the Royal Society of New Zealand, 1953, 81, 79-143.

Lom J. Notes on the ultrastructure and sporoblast development in fish parasitizing myxosporidian of the genus Sphaeromyxa. Z. Zellforsch, 1969, 97, 416-437.

Lom J. \& Arthur J.R. A guideline for the preparation of species descriptions in Myxosporea. Joumal of Fish Diseases, 1989, 12, 151-156.

Lom J. \& Dykovi I. Protozoan parasites of fishes. Amsterdam: Elsevier Science Publishers BV. Developments in Aquaculture and Fisheries Science, 1992, 26, 315 p.

Love M.S. \& MOSER M. A checklist of parasites of California, Oregon and Washington marine and estuarine fishes. NOAA Technical Report NMFS SSRF-777, 1983, 576 p.

Lubat V., Rajujkovic B., Marques A. \& Bouix G. Parasites des poissons marins du Montenegro: Myxosporidies. Acta Adriatica, 1989, 30, 31-50.

MacKenzie K. \& Longshaw M. Parasites of the hakes Merluccius australis and $M$. bubbsi in the waters around the Falkland Islands, southern Chile and Argentina, with an assessment of their potential value as biological tags. Canadian Joumal of Fisheries and Aquatic Sciences, 1995, 52, 213-224.

Margolis L., Esch G.W., Holmes J.C., Kuris A.M. \& SchaAd G. The use of ecological terms in parasitology. (Report of an ad hoc Committee of the American Society of Parasitologists). Journal of Parasitology, 1982, 68, 131-133.

MORRISON N.D. \& PRATT I. Sphaeromyxa maiyai sp. n. (Protozoa: Myxosporidea), coelozoic parasite of the Pacific tomcod, Microgadus proximus. Journal of Protozoology, $1973,20,214-217$

Morrison C.M. \& Hawkins W.E. Coccidians in the liver and testis of the herring Clupea harengus L. Canadian Journal of Zoology, 1984, 62, 480-493.

NOBLE E.R. Myxosporidia from the tide pool fishes of California. Joumal of Parasitology, 1939, 25, 359-364.

NoвLE E.R. On distribution relationships between California tide pool fishes and their Myxosporidian (Protozoan) parasites. Joumal of Parasitology, 1941, 27, 409-415. 
Saridella N.H. Descripción de la espora y de los estadíos previos del mixosporidio Kudoa rosenbuschi, parásito muscular de Merluccius bubbsi. Ciclo de vida. Parasitología al Dia. 1988a, 12, 8-13.

SARIDELA N.H. Secuencia de la infestación y reacciones tisulares en la musculatura de Merluccius hubbsi Marini ("merluzan) y de Micromesistius australis Norman ("polaca") por la presencia de mixosporidios del genero Kudoa Meglitsch. Parasitología al Día, 1988b, 12, 13-18.

SARIEI.IA N.H. \& Roldòn M.I. Mixosporidiosis producida por Kudoa rosenbuschi, parásito muscular de la merluza conún (Merluccius bubbsi) en la Zona Común de Pesca Argentino-Uruguaya. Frente Marítimo, 1989, 5, 83-85.

Sakileli.a N.H. \& Timi J.T. Parasite communities of Merluccius bubbsi from the Argentinean-Uruguayan Common Fishing Zone. Fisheries Research, 1996, 27, 81-88.

SARKAR N.K. A new myxosporidian Sphaeromyxa hareni sp. n. (Myxozoa: Myxidiidae) from an Indian marine teleost Trachysurus platystomus (Day). Acta Protozoologica, 1984. $23,183-186$.

SARKAR N.K. \& MAJLMDER S. Myxosporidian Sphaeromyxa dighaesp. n. (Myxozoa: Myxidiidae) from the gallbladder of Hilsa ilisha (Clupeidae). Acta Protozoologica, 1983, 22, 257-260.

SCHIILAN S.S. The myxosporidian fauna of the USSR (in Russian). Moscow-Leningrad, Nauka, 1966, 504 pp.

Su X. \& White W.G. New myxosporeans (Myxozoa: Myxosporea) from marine fishes of Tasmania, Australia. Acta Protozoologica, 1994, 33, 251-259.

Upton S.J., ReIJKer D.W. CuRrent W.L. \& Duszynski D.W. 'Taxonomy of North American fish Eimeriidae. NOAA Technical Report NMFS, 1984, 11, 18 p.

Reçu le 13 mai 1998 Accepté le 30 juillet 1998 